\title{
（22）千葉実験所における地震動観測
}

一 $の 3$ 観測記録に基づく距离隹減哀特性—

$\begin{array}{lc}\text { 東京大学大学院 } & \text { O安藤 } \\ \text { 東京大学大学院 } & \text { Turgay Türker } \\ \text { 東京大学生産技術研究所 片山 恒雄 }\end{array}$

1.はじめに

地表における最大加速度の距離減衰特性を明らかにすることは, 耐震工学の分野における重要なテーマの 一っである. 最大加速度の距離減衰式については様々な地盤条件のもとに, 各々異なったデータベース, 減 衰式モデル, 解析手法を用いて数多くの研究がなされている. 最大加速度はばらつきの幅が広く, そのため 観測値はしばしば予測値と大きく異なることがある. たとえば, ある一地震を取り上げ地震諸元のパラメー 夕を固定したとしても，ほぼ同一の地盤と考えられる小さな区域内においても観測値はばらつき，このよう な観点からの最大加速度予測值の定量的な検討も行われるべきだと考えられる．この報告においては，東京 大学生産技術研究所千葉実験所の地表 (GL-1m) で得られた記録に基づき, 最大加速度の距離減衰特性を求める ととすに, 実験所内の数 $m$ 百数十離れた地点間の最大加速度のばらつきについて評価する.

\section{2. 最大加速度の距離減衰式について}

使用デー夕の特性: 千葉実験所の地盤構造は大まかには地表面から関東ローム, 凝灰質粘土, 洪積砂とな っており, 道路橋示方書の示す 2 種地盤に分類される. 距離減衰特性の解析に用いた最大加速度記録はC0観 測孔の地表 (GL-1m) の地震計で得られたすのである. 対象としたのは1982年7月〜1988年10月に起こったマグ ニチュード2.9〜 7.9の141地震で, 震央位置分布は図 1 に示すように近距離小地震が多い. デー夕数は141成 分, 最大加速度の定義は水平 2 成分の最大値の大きい方を採用した. 震央距離は $1 \sim 819 \mathrm{~km}$ で, 最大加速度は 数gal, 数十galがほとんどであり, $100 \mathrm{ga}$ 以上のあのは, 千葉県東方沖地震の記録 (326gal)のみである（図 2 , 前報その 1 参照) . 表 1 に諸元間の相関係数, 表 2 に震央距離, マグニチュードによる地震の分類表を 示す.

最大加速度の距離減衰式 : 使用データは多地点記録ではないので, 層別因子を用いない最小 2 乗法により

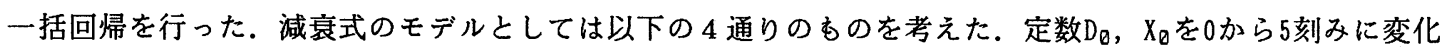

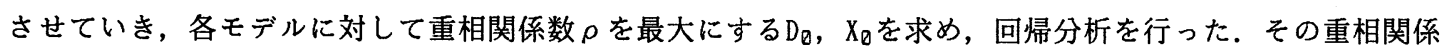
数を併記する.

(A) $\log A=a M+b \log \left(D+D_{\emptyset}\right)+d \quad \rho$ は 0.59

(B) $\log A=a M+b \log \left(X+X_{\square}\right)+d \quad \rho$ \& 0.63

(C) $\log A=a M+b \log \left(D+D_{B}\right)+c H+d \quad \rho$ は 0.60

(D) $\log A=a M+b \log \left(X+X_{\square}\right)+c H+d \quad \rho$ は 0.72

ここで $\mathrm{A}$ :最大加速度 $(\mathrm{gal}) \mathrm{M}:$ マグニチュード $\mathrm{X}$ :震源距離 $(\mathrm{km}) \mathrm{H}$ :震源深さ $(\mathrm{km}) \mathrm{D}$ :震央距離 $(\mathrm{km})$

モデル (C), (D) は震源深さの項cHを含んでおり, 震源深さを独立変数として評価しないモデル (A), (B)に比 べ重相関係数がかなり大きい. また震源深さの項を加えることによって, cの值が正であれば, 直下型地震に 対するモデル(B)の過大な距離減衰特性を補正することができる. 例えばマグニチュードが同一で震源深さH $=10 \mathrm{~km}$ とH $=100 \mathrm{~km}$ の地震が起こったとすれば, 震央における加速度予測值の比（前者の予測值 $/$ 後者の予測值） はモデル(B)の回帰結果で21程度, モデル(D)のあので11程度となった. モデル(B)では深さ方向の減衰が過大 に評価されているように思われる. またモデル(D)はマグニチュード, 震源距離が等しい地震については震源 深さの大きいむのほど大きな加速度を予測する．ょく似た傾向は既往の研究でも指摘されている(1)(2).

あっとす重相関係数の高かったモデル(D)を採用して回帰したのが次の減衰式である. 


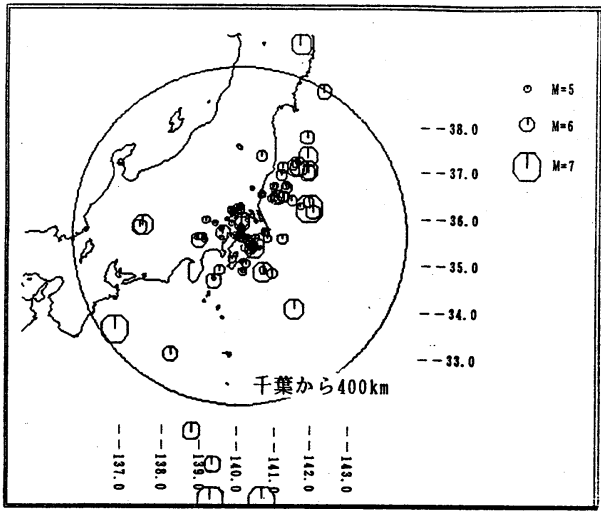

図 1 震央位置分布

表 1 諸元間の相関係数

\begin{tabular}{|c|c|}
\hline & $\therefore \angle 0 D D=100 B$ \\
\hline LOG A & $10.10960 \div 0.1730-0.2206-0.0516 \div 0.2182$ \\
\hline MAGNITUDE & $0.10960 \quad 10.737130 .855070 .467170 .72119$ \\
\hline 1060 & $10.821410 .37450 \quad 0.69879$ \\
\hline LOGR & $0.2206 \quad 0.85507 \quad 0.82141$ \\
\hline $\mathrm{H}$ & $-0.05160 .467470 .37450 \quad 0.64562$ \\
\hline$R$ & -0.21820 .721190 .698790 .210570 .81066 \\
\hline
\end{tabular}

表 2 対象地震のD, Mによる分類表

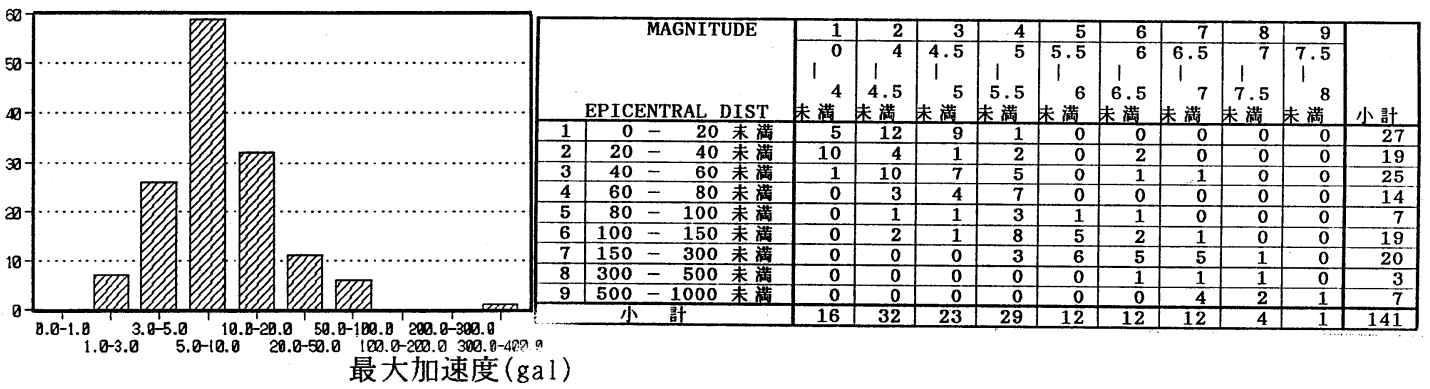

図 2 水平最大加速度の分布
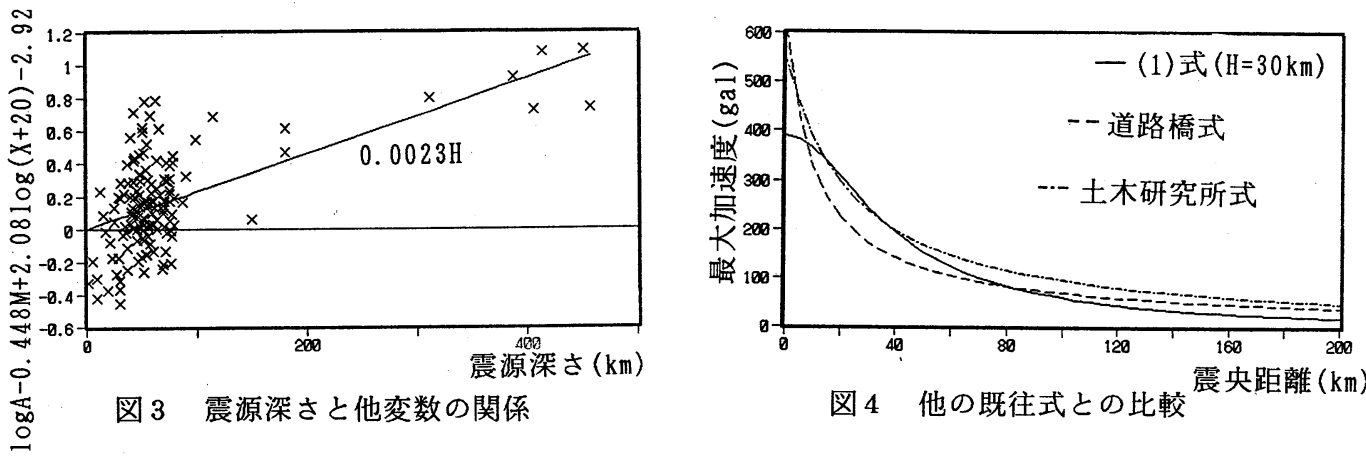

図 4 他の既往式との比較
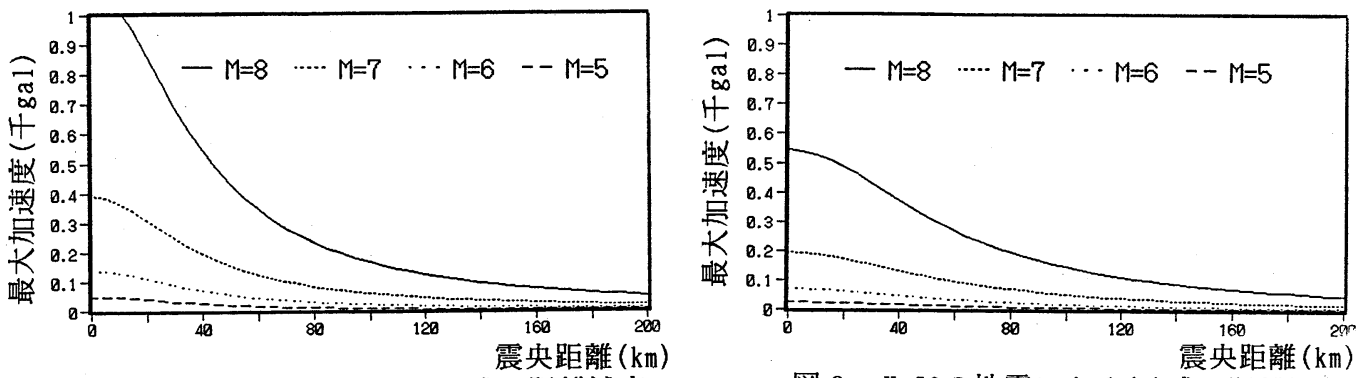

図 $5 \mathrm{H}=30$ の地震による(1)式の距離減衰 


$$
\sigma_{\log \mathrm{A}}=0.2437 \quad \rho=0.718
$$

図 3 に震源深さと(1)式の他の変数の関係を示す.この図を見れば， $\log \mathrm{A}$ 震源深さの 1 次関数を加えて回帰 しても差し支えないあのと思われる.

道路橋示方書の式(3)（2 種地盤）や土木研究所の式(4)（2 種地盤）（この両者は震源深さの情報を用い ていない）と式(1)の距離減衰特性を比較して図 4 に示す. 式(1)は従来のすのに比べて大きな距離隇衰効果 を示しているのが分かる。しかし, マグニチュードや震嫄距離などの説明変数の間に高い相関関係があるこ とや近距離大地震データがないことを考えると，使用データの諸元の範囲を超えて，この回帰式を適用する ことに関しては，さらに今後検討することが必要である.

3. 観測值のばらつきについて

最大加速度の式(1)による予測值と観測値を図 7 に示すが，これからす明らかなようにこの両者はしばしば 大きく異なる值を示すことがある．予測值の観測值からのばらつきは，重回帰分析時に得られる目的変数の 標準誤差 $\sigma_{\log A}$ で評価できる．このようなマクロな最大加速度のばらつきに加えて，ほとんどすべてのパ ラメータが等しいと思われる領域においてさえ観測值はばらつくのである．そこで千葉実験所のアレー観測 記録をむとに，同一地震の最大加速度観測値がどのくらいばらつくかを定量的に解析することを試みた．片 山ら (5) は千葉実験所の1982年〜1984年の最大加速度記録からそのばらつきを解析しているが，今回の解析で は空間的広がりの影響す考慮にいれた。観測地区はボーリング資料(6)によればほぼ成層構造を有しており， 地区内には地表地中あわせて44台の地震計が設置されている。それらの中から空間的な広がりの影響を考慮 し，以下のようなグループ分けを行った。（観測孔の配置は前報その 1 参照） GROUP1:地表 (GL-1m)の $5 \mathrm{~m}$ 区域内のCO, C1, C2, C3, C4観測孔の地震計 GROUP2 :地表 (GL-1m)の $15 \mathrm{m区}$ 域内のC0, P1, P2, P3, P4観測孔の地震計 GROUP 3 : 地表 (GL-1m) の約 $150 \mathrm{~m}$ 区域内のC0, P5, P6, P8, P0観測孔の地震計 GROUP4 : 地中 (GL-5m)の $5 \mathrm{~m}$ 区域内の $\mathrm{CO}, \mathrm{C1}, \mathrm{C2}, \mathrm{C3}, \mathrm{C} 4$ 観測孔の地震計 GROUP 5 : 地中 (GL-10m) の $5 \mathrm{~m}$ 区域内の C0, C1, C2, C3, C4観測孔の地震計

約10gal以上の最大加速度値が観測された 9地震（GROUP3は6地震）を，その震央方向 (R) 成分，震央直交方 向 (T) 成分, 上下動 (UD) 成分に分け, 各GROUPの変動係数を得た（表 3 , 図 $8 \sim 12$ ). その変動係数の平均 值を見るとR,T成分とすに，広がりが5mのGROUP 1 は約 $0.07 ， 15 \mathrm{~m}$ のGROUP2は約 $0.10 ， 150 \mathrm{~m}$ のGROUP 3 は約 0.15 と 距離の増加とともにばらつきの幅は大きくなる傾向にある。また地震計の埋設深度が大きければ，变動係数 は小さくなり, 埋設深さ10mのGROUP5は地表のGROUP1の半分の変動係数を示した. 震央方向成分, 震央直交方 向成分, 上下方向成分には変動係数に大きな傾向の違いはみられなかった.

4.あとがき

今回示した最大加速度の距離減衰式は, 既往のむのと比較しても重相関係数が高い方に位置づけられるす のと思われるが，対数軸上で 0.247 程度の標準誤差がある. 最大加速度を対数正規分布と仮定すれば約 $16 \% の$ 確率で予測值の1.7倍程度の值が現れる。このような大きな標準誤差がでる要因として文献(7)が詳しい．こ のような最大加速度の予測值の平均レベルのばらつきの問題のほかに, 最大加速度は小さな区域内において あ空間的にばらつき, 千葉実験所のデー夕においては変動係数0.07〜0.15程度を示す. 最大加速度を推定す る際は最大加速度がこのように大きくばらつく性質を考慮すべきすのだと考える.

\section{参考文献}

（1)安中他 (1987)第19回地震工学研究発表会, 129-132 （2)野田・山田(1981)第36回年次学術講演会, 395-396

(3) 日本道路協会 (1980) 道路橋示方書·同解説, 108 (4) 土木研究所 (1983) 土木研究所資料第1993号, 51 (5)片 山·佐藤 (1984)第39回年次学術講演会, 803-804 (6)片山(1986)地震動の工学的距離特性に関する害証的研究 (7) 田中·福島 (1987)第15回地盤振動シンポジゥム, 7-16 


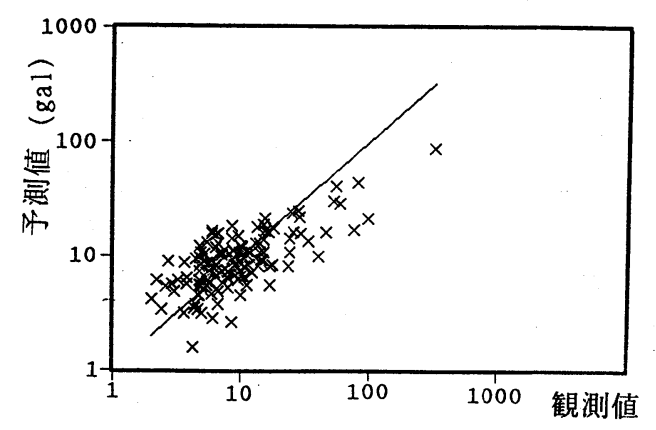

図 7 観測値と予測値の関係 （gal）

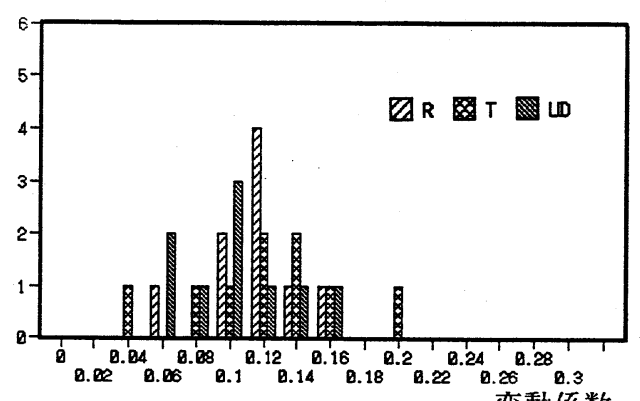

図 9 GROUP2 $(15 \mathrm{mGL}-1 \mathrm{~m})$ の変動係数分布

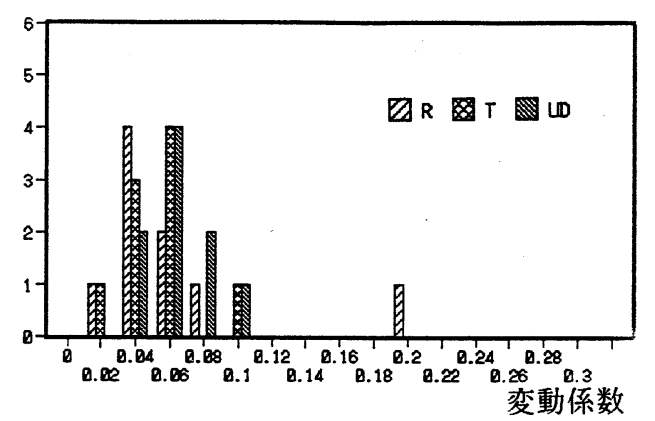

図 11 GROUP4 (5mGL-5m) の変動係数分布

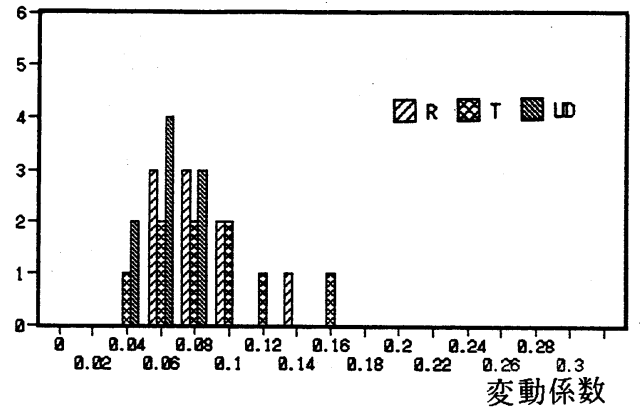

図 8 GROUP1 (5mGL-1m)の変動係数分布

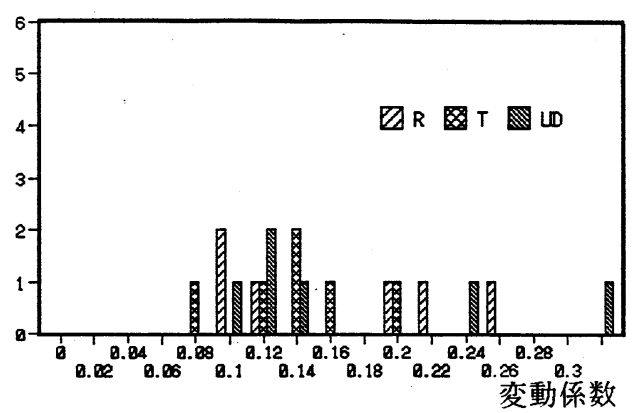

図 10 GROUP3 (150mGL-1m)の变動係数分布

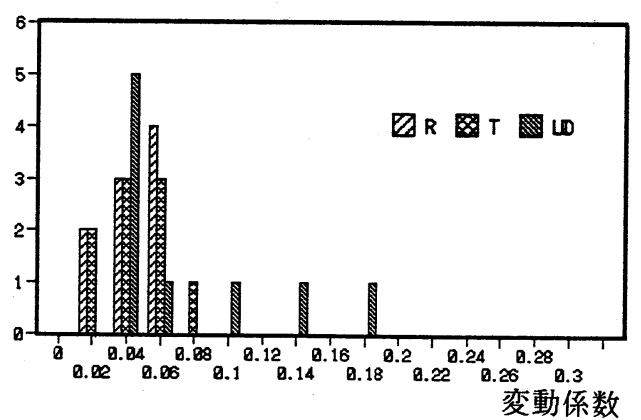

図 12 GROUP5 (5mGL-10m)の変動係数分布

表 3 各地震による加速度の変動係数

\begin{tabular}{|c|c|c|c|c|c|c|c|c|c|c|c|}
\hline DATE & $\begin{array}{c}\mathrm{Y} \\
\mathrm{M} / \mathrm{D}\end{array}$ & $\begin{array}{r}1985 \\
6 / 8 \\
\end{array}$ & $\begin{array}{l}1985 \\
10 / 4\end{array}$ & $\begin{array}{l}1985 \\
11 / 6 \\
\end{array}$ & $\begin{array}{l}1986 \\
2 / 12 \\
\end{array}$ & $\begin{array}{l}1987 \\
12 / 17\end{array}$ & $\begin{array}{l}1987 \\
12 / 17\end{array}$ & $\begin{array}{l}1988 \\
1 / 16\end{array}$ & $\begin{array}{r}1988 \\
3 / 18 \\
\end{array}$ & $\begin{array}{l}1988 \\
8 / 12\end{array}$ & \\
\hline MAGNI' & rUDEkm & 4.8 & 6.1 & 5.0 & 6.1 & 6.7 & 4.6 & 5.2 & 6.0 & 5.3 & \\
\hline DEPTH & $\mathrm{km}$ & 64 & 78 & 63 & 44 & 58 & 48 & 53 & 99 & 66 & \\
\hline D & $\mathrm{km}$ & 16 & 28 & 32 & 125 & 46 & 50 & 42 & 42 & 61 & AVG \\
\hline GRO & $\mathbf{R}$ & 0.081 & 049 & 047 & .063 & 053 & 0.120 & 0.068 & 080 & .066 & \\
\hline 5 & $\mathrm{~T}$ & 85 & 76 & 38 & 152 & 87 & 0.102 & 43 & 62 & 55 & \\
\hline $\mathrm{GL}-1 \mathrm{~m}$ & UD & 67 & 0.063 & 38 & .046 & 0.052 & 0.041 & 0.063 & 033 & 43 & \\
\hline GROUP2 & $\mathbf{R}$ & 04 & 0.108 & 16 & .151 & 0.082 & 0.131 & 0.094 & 0.104 & 50 & \\
\hline & $T$ & 83 & 0.123 & 0 . & .082 & 155 & 0.116 & 0.074 & 136 & 10 & 13 \\
\hline & UD & & 53 & & .061 & .112 & 0.083 & 0.093 & 124 & 48 & 90 \\
\hline GRC & $\mathrm{R}$ & 83 & 0.248 & 0.105 & 0.197 & & & & 0.210 & 0.091 & $5 \overline{6}$ \\
\hline 15 & $\mathrm{~T}$ & 25 & 0.140 & 69 & 180 & & & & 111 & 120 & 4 \\
\hline $1 \mathrm{~m}$ & UD & 32 & 0.117 & 0. & 82 & & & & .447 & 32 & \\
\hline BROUP4 & $\bar{R}$ & 17 & 0.032 & 0 . & 0.071 & $\overline{33}$ & 186 & 0.057 & 0.031 & 0.048 & $\overline{5} \overline{6}$ \\
\hline 5 & $\mathrm{~T}$ & 37 & 0.015 & 54 & 0.090 & 32 & 048 & 48 & 0.027 & 41 & 43 \\
\hline$-5 m$ & UD & 52 & 41 & 26 & 52 & 0.075 & 0.032 & 0.086 & 0.062 & 0.040 & 52 \\
\hline GROUP5 & $\mathbf{R}$ & 0.037 & 0.018 & 0.043 & 0.043 & 0.041 & 0.038 & 0.045 & 0.023 & 0.007 & 33 \\
\hline $5 n$ & $\mathrm{~T}$ & 27 & 0.027 & 0.026 & 0.072 & 0.014 & 0.041 & 0.047 & 0.040 & 0.019 & 0.035 \\
\hline - & UD & 34 & 32 & 21 & 36 & 045 & 080 & 0.163 & 0.034 & 0.036 & b.065 \\
\hline
\end{tabular}

